\title{
THE VARIABILITY OF REED \\ [PHRAGMITES AUSTRALIS (CAV.) TRIN. EX STEUD. (POACEAE)] POPULATIONS EXPRESSED IN MORPHOLOGICAL TRAITS OF PANICLES
}

\author{
Maria KRZAKOWA ${ }^{1}$, MirosŁaWA KoŁODZIEJCZAK, \\ MARIA DRAPIKOWSKA ${ }^{2}$, HANNA JAKUBIAK ${ }^{1}$ \\ ${ }^{1}$ Department of Genetics, Adam Mickiewicz University \\ Miedzychodzka 5, 60-371 Poznan, Poland \\ e-mail: krzakowa@main.amu.edu.pl \\ 2 Department of Ecology and Environmental Protection, \\ University of Agriculture \\ Wojska Polskiego 71e, 60-625 Poznan, Poland \\ e-mail:mariadra@owl.au.poznan.pl
}

(Received: July 26, 2002. Accepted: September 26, 2002)

\begin{abstract}
Using a transect technique, each of 12 reed Phragmites australis (Cav.) Trin ex Steud. populations collected in middle part of Odra River-basin, represented by more than 30 plants, were compared with 3 populations from other part of the country and 1 from France. Each panicle was examined according to 15 morphological traits. Results of measurements were subjected to multivariate analysis of variance, to analysis of canonical variables and used for construction of a minimum spanning tree (= dendrite) on the basis of the shortest Mahalanobis distances. The obtained results indicate that populations are generally similar. One population from France (Orleans) shows visible separateness. It may suggest that morphological traits of panicles may be useful in investigations of the reed $P$. australis populations of a larger geographical distribution.
\end{abstract}

KEY WORDS: Phragmites australis, panicle morphology, intra-specific variation.

\section{INTRODUCTION}

The reed Phragmites australis (Cav.) Trin ex Steud., the most important species of land-water ecotones, can grow in localities of a wide range of water content. Usually, it can be found growing in the lake shore area or periodically flooded river banks as well as in any humid soil. This ability to exist in such different ecological conditions is likely to have some influence on the plant's morphological variability.

It is a clonal plant i.e. plant producing offspring that is a copy of the maternal plant (by means of vegetative spread). There are strong indications that reed populations may be highly variable with respect to the clonal structure. Some populations are suspected to be monoclonal, most others, however, turned out to be polyclonal. Many clonal populations show variations in morphological character which usually show polygenic inheritance. Differences in the morphological type of reed shoots and leaves growth (Björk 1967; Dykyjova 1973; Szajnowski 1973), density and biomass (Mohnacka-Lawacz 1974; Dykyjova and Veber 1978; Szczepański 1978) as well as grains dimention and shape (Kraska and Bobowicz 1987; Kraska et al. 1986, 1992) were examined intensively. Unfortunately, quantitative characters (such as leaf morphology) cannot be used to identify individual genets. There is prevailing assumption that sexual organs are not so sensitive on environmental changes as vegetative parts of plants. In our study, the variability of 15 traits of panicles is investigated with the aim to describe interpopulational differences, since they were introductory examined according to enzyme variability (Krzakowa 1996).

\section{MATERIAL AND METHODS}

Panicles were collected from 16 populations. Twelve of them were situated along the middle part of the Odra River, spread on its drainage-basin in the area of over $100 \mathrm{~km}$ (Fig. 1). The other four populations were included for 


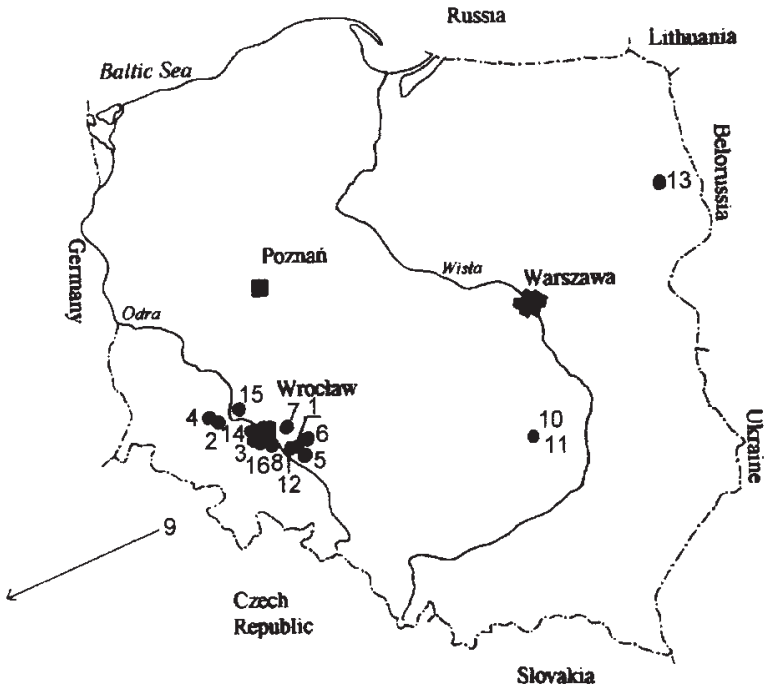

Fig. 1. Location of Phragmites australis (Cav.) Trin. ex Steud. populations.

1 - Janików, water-course, 2 - Jaśkowickie Lake, 3 - Krobielowice, draining canal, 4 - Kunickie Lake, 5 - Mąkoszyce, lakelet, 6 Namysłów, pond, 7 - Oleśnica River, 8 - Oława River, 9 - Orlean Loire River bank, 10 - Starachowice, rail track side, 11 - Pasternik flood on Kamienna River, 12 - Stary Górnik, stream, 13 - Supraśl River, 14 Ślęża brook 15 - Wołów, drainage canal, 16 - Wrocław height Odra River bank.

comparison. The two first from Starachowice (Nos. 10 and 11) were over $300 \mathrm{~km}$ away from the main group and grow in dramatically different water conditions: population No. 10 was collected at dry, rail track side, while population No. 11 - in its close $(500 \mathrm{~m})$ at Pasternik Flood on Kamienna River. The third neighbourghood. The third population (No. 13) grows on the Supraśl River bank in NE Poland. The last one (population No. 9) represents the reed from southern France, collected in Orleans on the Loire River bank. In each population panicles were collected from more than 30 randomly chosen adult plants. Populations differed significantly according to their growth (1.5-3.3 m). Totally, 531 plants were examined according to 15 characters (Fig. 2).

The results of measurements were passed to the Computing Centre at the Agriculture Academy in Poznań to com-

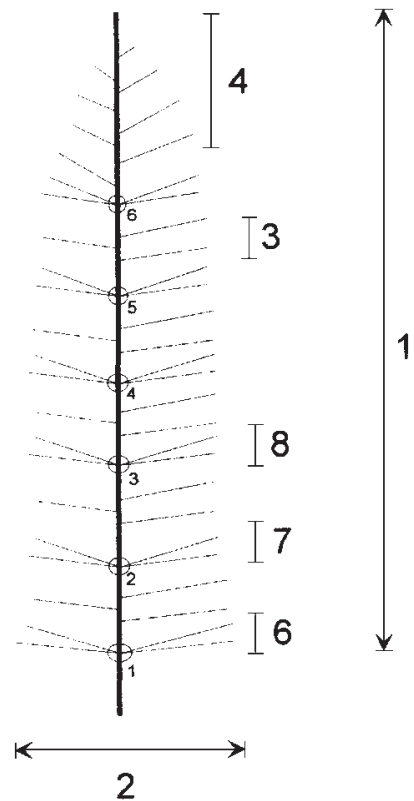

Fig. 2. The scheme of measuring procedure of the panicle (trait No. 5 - number of verticils i.e. 1-6). Orig.

pute: 1) trait characteristics, 2) multivariate analysis of variance (Morrison 1990), 3) Distances between populations illustrated by minimum spanning tree (= dendrite) constructed on the basis of Mahalonbis's distances. (Łomnicki 1998), 4) Principal Component Analysis (Morrison 1990).

\section{RESULTS AND DISCUSSION}

Trait characteristics (Table 1) show that the most variable character is the number of lateral branches: some panicles have 5, some others even 18 . The common number of whorls was 15 however, because some individuals do not possess all 15 whorls, (for example, only 10), the coefficient of variability counted for the last four traits is extremely high.

Correlation coefficients calculated for particular pairs of all traits (Table 2) indicate that the highest correlation was noted between the first two, as well as between the six pairs of characters. Significant differentiation of individuals was confirmed by testing particular hypotheses $\mathrm{H}(0.1)$ -

TABLE 1. Characteristics for 15 panicle traits of Phragmites australis (Cav.) Trin. ex Steud.

\begin{tabular}{|c|c|c|c|c|c|}
\hline Traits & $\mathrm{X}$ & SD & $\mathrm{CV} \%$ & $\mathrm{x}_{\text {min. }}$ & $\mathrm{X}_{\max }$ \\
\hline 1. Panicle length & 29.36 & 5.46 & 18.61 & 13.00 & 48.00 \\
\hline 2. Panicle spread & 27.62 & 6.56 & 23.75 & 10.00 & 46.00 \\
\hline 3. Number of lateral ramifications & 25.11 & 11.52 & 45.99 & 1.00 & 68.00 \\
\hline 4. Number of top ramifications & 12.98 & 7.26 & 55.97 & 1.00 & 41.00 \\
\hline 5. Total whorls number & 6.88 & 3.01 & 43.73 & 1.00 & 18.00 \\
\hline 6. Number of lateral branches in the first whorl & 6.84 & 2.50 & 36.59 & 2.00 & 21.00 \\
\hline 7. Number of lateral branches in the second whorl & 5.71 & 2.45 & 42.85 & 0.00 & 20.00 \\
\hline 8. Number of lateral branches in the third whorl & 4.70 & 2.31 & 49.17 & 0.00 & 14.00 \\
\hline 9. Number of lateral branches in the fourth whorl & 3.79 & 2.30 & 60.71 & 0.00 & 18.00 \\
\hline 10. Number of lateral branches in the fifth whorl & 2.91 & 2.23 & 76.70 & 0.00 & 15.00 \\
\hline 11. Number of lateral branches in the sixth whorl & 2.23 & 2.22 & 99.49 & 0.00 & 12.00 \\
\hline 12. Number of lateral branches in the seventh whorl & 1.50 & 1.88 & 125.1 & 0.00 & 9.00 \\
\hline 13. Number of lateral branches in the eighth whorl & 1.14 & 1.84 & 162.4 & 0.00 & 14.00 \\
\hline 14. Number of lateral branches in the ninth whorl & 0.77 & 1.37 & 177.8 & 0.00 & 8.00 \\
\hline 15. Number of lateral branches in the tenth whorl & 0.57 & 1.31 & 228.6 & 0.00 & 9.00 \\
\hline
\end{tabular}

Arithmetical means (x), standard deviations (SD), variation coefficient (CV), minimum and maximum values. 
TABLE 2. Correlation coefficients for 1-15 panicle traits of the reed Phragmites australis (Cav.) Trin. ex Steud.; for details see Table $1 .(*=0.01, * *=0.05)$.

\begin{tabular}{|c|c|c|c|c|c|c|c|c|c|c|c|c|c|c|}
\hline 2 & $0.78^{* *}$ & & & & & & & & & & & & & \\
\hline 3 & $0.19 * *$ & $0.13 * *$ & & & & & & & & & & & & \\
\hline 4 & 0.04 & $-0.11 *$ & $-0.21 * *$ & & & & & & & & & & & \\
\hline 5 & $0.21^{* *}$ & 0.19 ** & $-0.16^{* *}$ & $-0.14 * *$ & & & & & & & & & & \\
\hline 6 & $0.10^{*}$ & $0.11 * *$ & $0.18 * *$ & -0.04 & $0.15^{* *}$ & & & & & & & & & \\
\hline 7 & $0.27 * *$ & $0.25 * *$ & 0.07 & 0.02 & $0.33 * *$ & $0.44 * *$ & & & & & & & & \\
\hline 8 & $0.25 * *$ & $0.19 * *$ & 0.02 & 0.07 & $0.45 * *$ & $0.29 * *$ & $0.57 * *$ & & & & & & & \\
\hline 9 & $0.23 * *$ & $0.19 * *$ & -0.03 & 0.04 & $0.58 * *$ & $0.30 * *$ & $0.55^{* * *}$ & $0.66 * *$ & & & & & & \\
\hline 10 & $0.26^{* *}$ & $0.18 * *$ & -0.04 & 0.06 & $0.64 * *$ & $0.22 * *$ & $0.46^{* * *}$ & $0.54^{* *} *$ & $0.72 * *$ & & & & & \\
\hline 11 & $0.25^{* *}$ & $0.21 * *$ & $-0.11 * *$ & 0.05 & $0.72 * *$ & $0.20 * *$ & $0.38 * *$ & $0.49 * *$ & $0.61 * *$ & $0.76 * *$ & & & & \\
\hline 12 & $0.23 * *$ & $0.18 * *$ & $-0.13 * *$ & $-0,00$ & $0.78 * *$ & $0.19 * *$ & $0.31 * *$ & $0.41 * *$ & $0.54 * *$ & $0.62 * *$ & $0.76 * *$ & & & \\
\hline 13 & $0.25^{* *}$ & $0.20 * *$ & $-0.18^{* *}$ & 0.03 & $0.73 * *$ & $0.12 * *$ & $0.27 * *$ & $0.36 * *$ & $0.46 * *$ & $0.49 * *$ & $0.65 * *$ & $0.79 * *$ & & \\
\hline 14 & $0.25 * *$ & $0.19 * *$ & $-0.10^{*}$ & -0.06 & $0.78 * *$ & $0.17 * *$ & $0.31 * *$ & $0.41 * *$ & $0.44 * *$ & $0.46 * *$ & $0.61 * *$ & $0.71 * *$ & $0.80 * *$ & \\
\hline \multirow[t]{2}{*}{15} & $0.21 * *$ & $0.16 * *$ & $-0.15^{* *}$ & -0.04 & $0.72 * *$ & $0.14 * *$ & $0.27 * *$ & $0.33 * *$ & $0.34 * *$ & $0.40 * *$ & $0.50 * *$ & $0.58 * *$ & $0.65 * *$ & $0.79 * *$ \\
\hline & 1 & 2 & 3 & 4 & 5 & 6 & 7 & 8 & 9 & 10 & 11 & 12 & 13 & 14 \\
\hline
\end{tabular}

TABLE 3. Results of statistical hypothesis testing in MANOVA TEST defining differentiation of Phragmites australis (Cav.) Trin. ex Steud. in respect to 15 panicle traits.

\begin{tabular}{|c|c|c|c|}
\hline Hypotheses & F. calc & Hypotheses & F calc. \\
\hline $\mathrm{H}(0.1)$ & 29.02 & $\mathrm{H}(0.8)$ & 9.82 \\
\hline $\mathrm{H}(0.2)$ & 36.99 & $\mathrm{H}(0.9)$ & 13.86 \\
\hline $\mathrm{H}(0.3)$ & 9.60 & $\mathrm{H}(0.10)$ & 13.68 \\
\hline $\mathrm{H}(0.4)$ & 12.88 & $\mathrm{H}(0.11)$ & 14.79 \\
\hline $\mathrm{H}(0.5)$ & 19.27 & $\mathrm{H}(0.12)$ & 17.51 \\
\hline $\mathrm{H}(0.6)$ & 6.95 & $\mathrm{H}(0.13)$ & 21.27 \\
\hline \multirow[t]{2}{*}{$\mathrm{H}(0.7)$} & 9.44 & $\mathrm{H}(0.14)$ & 18.17 \\
\hline & & $\mathrm{H}(0.15)$ & 14.01 \\
\hline
\end{tabular}

$\mathrm{F}_{0,05}=1.69 ; \mathrm{F}_{0,01}=2.07$

-H (0.15) separate for each of the 15 traits, as shown in Table 3. Inter-population variability based on panicle traits was reflected by the scatter diagram (Fig. 3) of the studied populations in the system of two canonical variables (totally, $62.35 \%$ of information). The pattern indicates that the examined populations are divided into two groups, compo-

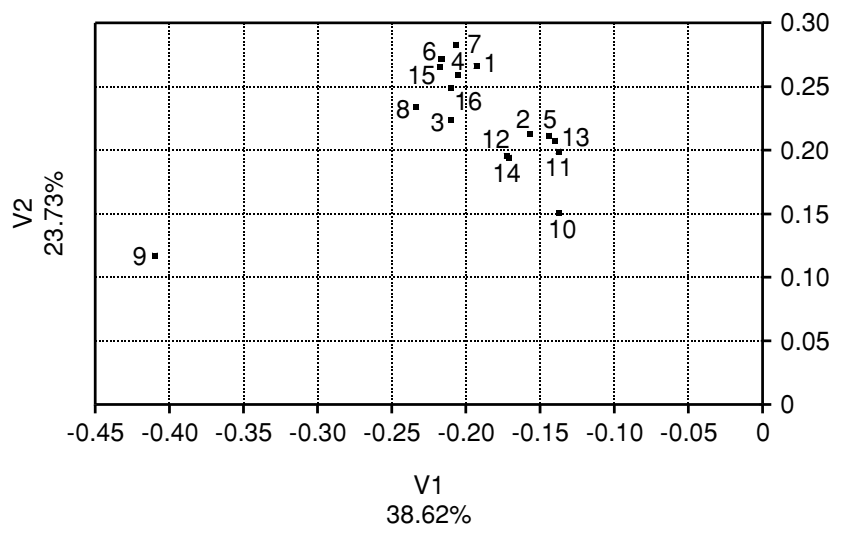

Fig. 3. Scatter diagram for 16 Phragmites australis (Cav.) Trin. ex Steud. populations on the plane of the two first canonical variables. sed of 7 and 8 populations, not connected with environmental conditions. The most distant is population No. 9 from Orleans (France). Differences in morphological characters of panicles are probably caused by some genetic pre-dispositions (polygenic influence) to develop panicles of different shape. The minimum spanning tree constructed on the basis of the shortest Mahalanobis distances (Fig. 3) shows other configuration of examined populations when compared to that on the plain of the two principal component axes (Fig. 2). Generally, populations are connected by very similar values (Fig. 4), although the small hiatus between the two groups (composed of 5 and 10 populations respectively) is visible. Again, the most distant is population No. 9 from the Loire River bank collected in Orleans (Fig. 3).

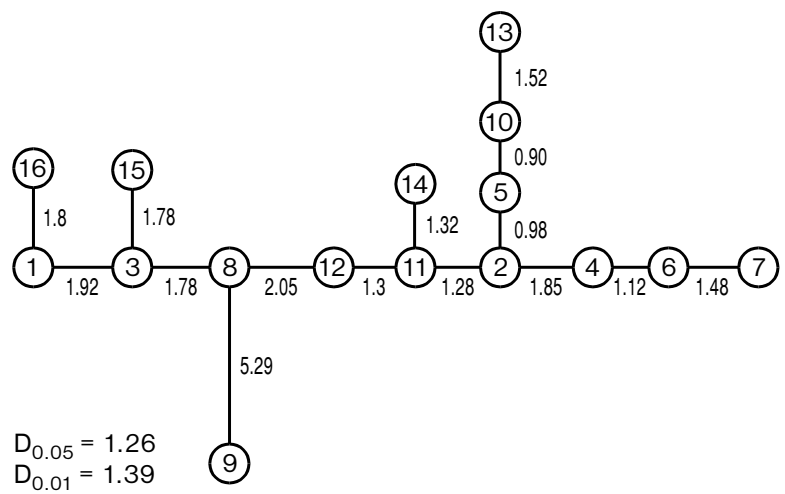

Fig. 4. Minimum spanning tree (= dendrite) constructed on the basis of Mahalanobis's distances for 16 reed populations in respect to 15 panicle traits.

An increasing number of studies during the last two decades have revealed that clonal plants have the same level of genetic diversity as non-clonal plants. (Ellstrand and Roose 1987; Hamrick and Godt 1990) Genetic variability 
of the same populations, described in the present paper, were earlier investigated by enzyme electrophoresis (Krzakowa 1996). Individual plants show genotypes composed of the two polymorphic peroxidase loci: one locus with two alleles and second with three alleles. The third peroxidase locus was constant and monomorphic in all populations. The most variable, according to peroxidase examinations, were the following populations: No. 2 (Jaśkowickie Lake), No. 14 (Ślęża River) and No. 8 (Oława River). No one population was monomorphic.

Morphological differences in panicle traits show individual differences between plants. Allozyme diversity (Krzakowa 1996; Krzakowa and Drapikowska 2000), between genets prove that common reed (Phragmites australis) populations have polyclonal character.

\section{LITERATURE CITED}

BJÖRK S. 1967. Ecologic investigations of Phragmites communis. Studies in theoretic and limnology. Folia Limnol. Scand. 14: $1-248$

DYKYJOVA D. 1973. Species differences in vertical structures and radiation profiles in the halophyte stands. Ecosystem study on Wetland Biome in Czechoslovakia. Czechosl. IBP/ PTPP Report No. 3. Trebon 1973; 121-131.

DYKYJOVA D., VEBER K. 1978. Experimental hydroponic cultivation of halophytes. In: D. Dykyjova, J. Kvet (eds.). Ecological studies, 28: 181-192. Springer Verlag Berlin, Heidelberg.

ELLSTRAND N.C., ROOSE M.L. 1987. Patterns of genotypic diversity in clonal plant species. Amer. J. Bot. 74: 123-131.

HAMRICK J.L., GODT M.J., 1990. Allozyme diversity in plant species. In: A.H.D. Brown, M.T. Clegg, A.L. Kahler, B.S. Weir (eds). Plant population genetics, breeding and genetic resources. Sinauer, Sunderland, MA, pp. 43-63.
KRASKA M., BOBOWICZ M. 1987. Biometric analysis of caryopses different stands of Phragmites australis (Cav.) Trin. ex. Steud. Arch. Hydrobiol. Beib. 1: 223-229.

KRASKA M., BOBOWICZ M., ARCZYŃSKA E. 1986. Morphological differences between stands of Phragmites australis (Cav.) Trin. ex. Steud. in cold and heated waters of Pątnowskie Lake, determined by measurements of caryopses. Arch. Hydrobiol. Beib. 2: 163-171.

KRASKA M., PODOLSKI G., PODOLSKA M. 1992. Germination under various culture conditions of reed caryopses Phragmites australis (Cav.) Trin. ex. Steud. from Lake Pątnowskie (near Konin, Poland) with heated water. Acta Hydrobiol. 34 (3): 213-225.

KRZAKOWA M. 1996. Genetic diversity of Phragmites australis (Cav.) Trin. ex. Steud. revealed by electrophoretically detected differences in peroxidases. In: C. Obinger, U. Burner, R. Ebermann, C. Penel, H. Greppin (eds). Plant Peroxidases: Bichemistry and Physiology. University of Geneva: 184-189.

KRZAKOWA M., DRAPIKOWSKA M. 2000. Sexual reproduction of Phragmites australis (Poaceae) in Baczkowski Pond (Poznan, Poland) revealed by peroxidase polymorphism. Biol. Bul. of Poznan. 37, 1: 43-53.

ŁOMNICKI A. 1995. Wprowadzenie do statystyki dla przyrodników. PWN, Warsaw (in Polish).

MOHNACKA-ŁAWACZ H. 1997. Seasonal changes of Phragmites communis Trin. Part. I. Growth, morphometrics, density and biomass. Pol. Arch. Hydrobiol. 21: 355-368.

MORRISON D.F. 1990. Wielozmienna analiza statystyczna. PWN, Warsaw (in Polish).

SZAJNOWSKI F. 1973. Relationship between leaf area index and shot production of Phragmites communis Trin. Pol. Arch. Hydrobiol. 20 (2): 257-268.

SZCZEPAŃSKI A. 1978. Ecology of macrophytes in wetlands. Pol. Ecol. Stud. 4: 45-94.

\title{
ZMIENNOŚĆ TRZCINY POSPOLITEJ \\ [PHRAGMITES AUSTRALIS (CAV.) TRIN. EX STEUD. (POACEAE)] POD WZGLĘDEM CECH MORFOLOGICZNYCH WIECHY
}

\begin{abstract}
STRESZCZENIE
W środkowym biegu Odry zebrano 12 populacji trzciny ( $P$. australis) metodą transektu i przyrównano do nich trzy populacje z innych regionów kraju oraz jedną populację z Francji. Z każdej populacji zebrano przynajmniej 30 roślin, których wiechy scharakteryzowano za pomocą 15 cech. Uzyskane dane opracowano metodami statystycznymi stosując wielozmienną analizę wariancji. Wyniki wskazują na małe różnice między polskimi populacjami, zaś populacja francuska jest wyraźnie odmienna. Nie wykluczone, że cechy morfologiczne wiechy mogą okazać się przydatne do określania różnic między populacjami geograficznie odległymi.
\end{abstract}

SŁOWA KLUCZOWE: Phragmites australis, morfologia wiechy, zmienność wewnątrzgatunkowa. 